\title{
The Incidence and Consequences of Filter Vent Blocking amongst British Smokers*
}

\author{
by \\ Richard R. Baker, Mike Dixon, \\ British American Tobacco, \\ Southampton, U.K. \\ and Colin A. Hill \\ Imperial Tobacco Ltd., \\ Bristol, U.K.
}

\section{SUMMARY}

Vent blocking, the intentional or unintentional covering of the filter ventilation holes during smoking, is an aspect of smoking behavior which could influence mainstream smoke yields. This study was designed to determine if, and to what extent, vent blocking by smokers' lips occurs. Three groups of British smokers were asked to smoke their own brand of cigarette which was either an unventilated filter brand, or one of two brands containing different levels of filter ventilation. 300 Smokers were used in each group and the filter butts were collected. Approximately 10 filter butts per smoker were collected. The filter tipping papers were removed and treated with a ninhydrin solution. This stained the saliva imprint on the paper so that the mouth insertion depth of the cigarette could be measured. In addition, levels of retained nicotine on the filters were also determined. This, together with the known filtration efficiencies of the filter, enabled an estimate to be made of the mainstream nicotine yield of the cigarette during the smoking.

The results indicate that British smokers have an average insertion depth of about $8.5 \mathrm{~mm} .85 \%$ of the

\footnotetext{
* Received: $26^{\text {th }}$ May 1998 - accepted: $22^{\text {nd }}$ July 1998; Presented, in part, at the CORESTA Smoke and Technology Groups' Joint Meeting, Hamburg, Germany, September 1997.
}

ventilated filters examined showed no vent coverage by the smokers' lips, $15 \%$ showed some coverage. Based on the techniques used in the present study it appears that the presence or absence of filter ventilation zone coverage by lips is not reflected in the estimated nicotine yields to smokers. It is likely that other smoker behavior factors have a more substantial role in determining nicotine yields within each cigarette delivery category.

\section{ZUSAMMENFASSUNG}

Das absichtliche oder zufällige Abdecken der Ventilationslöcher beim Rauchen einer Cigarette ist ein Aspekt des Rauchverhaltens, der Einfluß auf die Inhaltsstoffe des Cigarettenhauptstromrauchs haben könnte. Diese Studie wurde durchgeführt um festzustellen, ob und in welchem Ausmaß die Ventilationslöcher beim Rauchen durch die Lippen des Rauchers abgedeckt werden. Drei Gruppen britischer Raucher wurden gebeten, ihre eigenen Cigarettenmarken zu rauchen, dies waren entweder unventilierte Filtercigaretten oder mittlere bzw. stark ventilierte Cigaretten. In jeder Gruppe befanden sich 300 Raucher, von denen die Stummel gesammelt wurden, von jedem Raucher waren dies ungefähr 10 Stummel. Das Filtermundstück wurde entfernt und mit NinhydrinReagenz behandelt. Dadurch wurde der Speichel- 
abdruck auf dem Papier sichtbar gemacht, so dass die Einstecktiefe der Cigarette in den Mund gemessen werden konnte. Zusätzlich wurde auch die Menge des in den Filtern zurückgehaltenen Nikotins gemessen. In Kombination mit der bekannten Filterretention der Cigarettenfilter war es hierdurch möglich, die sich während des Rauchens ergebende Ausbeute an Nikotin im Cigarettenhauptstromrauch zu schätzen. Die Ergebnisse haben gezeigt, dass die durchschnittliche Einstecktiefe bei britischen Rauchern $8,5 \mathrm{~mm}$ beträgt. Bei $85 \%$ der untersuchten ventilierten Filter wurden die Ventilationslöcher nicht durch die Lippen des Rauchers abgedeckt, bei $15 \%$ wurden die Ventilationslöcher teilweise abgedeckt. Nach der in dieser Studie angewandten Technik scheint das Abdecken oder nicht Abdecken der Ventilationslöcher durch die Lippen des Rauchers nicht in Zusammenhang mit der geschätzten Nikotinausbeute beim Rauchen zu stehen. Es ist wahrscheinlich, dass andere Faktoren des Rauchverhaltens bei jeder Cigarettenkategorie eine größere Auswirkung auf die aufgenommene Nikotinmenge haben.

\section{RESUME}

L'obstruction intentionnelle ou accidentelle des trous de ventilation est un aspect du mode de fumage qui pouvait avoir une influence sur la composition de la fumée du courant principal. L'objectif de cette étude était d'examiner si et dans quelle mesure les trous de ventilation étaient obstrués par les lèvres des fumeurs en cours du fumage. Trois groupes de fumeurs britanniques ont fumé leurs propres marques, à savoir les cigarettes sans ventilation ou les cigarettes modérément ou fortement ventilées. Chaque groupe était composé de 300 fumeurs dont les mégots de cigarettes ont été recueillis, ce qui étaient approximativement 10 mégots par fumeur. Le papier de bout a été enlevé et traité avec une solution de ninhydrine. Ainsi on a pu apercevoir les taches de salive sur le papier ce qui a permis de mesurer la profondeur d'insertion de la cigarette. En outre on a déterminé la teneur en nicotine retenue sur les filtres. En connaissant l'efficacité des filtres ceci a permis d'estimer le taux de nicotine dans la fumée du courant principal en cours de fumage d'une cigarette.

Les résultats indiquent que les fumeurs britanniques ont une profondeur d'insertion moyenne d'environ $8,5 \mathrm{~mm}$. $85 \%$ des filtres ventilés examinés ne démontraient aucune trace d'obstruction des orifices par les lèvres des fumeurs, $15 \%$ étaient partiellement obstrués. D'après la technique utilisée dans cette étude la présence ou absence d'obstruction des trous de ventilation en cours du fumage ne reflète pas le taux estimé de nicotine retenu par les fumeurs. Il est probable que d'autres modes de fumage jouent un rôle plus substantiel dans l'ampleur des teneurs en nicotine dans la fumée du courant principal des différentes catégories de cigarettes.

\section{INTRODUCTION}

Since the early 1980s a number of studies have been published which have been interpreted to imply that about $50 \%$ of smokers of ventilated filter cigarettes cover the ventilation holes during smoking with their fingers, lips or even with tape (1). This estimate has been obtained largely through observation of the smoke condensate staining pattern on discarded cigarette butts or by direct interviews with smokers. Such blocking would have the effect of increasing the yields of mainstream smoke components over and above those obtained with unblocked holes. In a recent review of the subject (2), previously unpublished work undertaken by the tobacco industry was also considered, including video-recorded observations of smoking behavior and determination of cigarette-mouth insertion depths. It is inferred from the various studies, taken as a whole, that some smokers may cover some of the ventilation holes for at least one puff during smoking, but the behavior is not as widespread as claimed. In particular, ventilation hole coverage by fingers is relatively small - less than $4 \%$ of smokers have their fingers near the cigarette at all during all puffs.

The present study was devoted to assessing the incidence and consequences of ventilation zone coverage by lips. Its objectives were:

To determine the incidence of ventilation zone coverage by lips amongst lights and ultra lights British smokers using a staining technique for detecting dried saliva on the filter tipping paper.

To estimate the effect of covering the ventilation zone on nicotine yields of the smoker.

\section{EXPERIMENTAL DETAILS}

\section{Smoking Protocol}

Three British filter cigarette brands were used in this study, all $100 \mathrm{~mm}$ long, $25 \mathrm{~mm}$ circumference with $26 \mathrm{~mm}$ long filter tips and $30 \mathrm{~mm}$ long filter tipping paper. The cigarettes are designated as Standard (full flavor, with non-ventilated filter), Light (ventilated filter) and Ultra Light (ventilated filter) - details are given in Table 1. One packet of twenty cigarettes of each brand, together with a small aluminum container with a screw top, was sent by post to 300 
smokers of that brand from Imperial Tobacco in Bristol. Each smoker was asked to smoke the cigarettes in the normal way during their day-to-day activities. When each cigarette was finished the smokers were told not to stub it out but to put it in the container provided and screw on the lid. The cigarette then extinguished in less than one minute. When 10 butts had been collected the smokers returned the container and butts to Bristol.

Approximately $80 \%$ of the smokers returned the butts. Butts from 208 smokers of each brand were sent for analysis; insertion depth data from 207, 202 and 207 smokers were subsequently obtained for the three brands respectively. Of these 208 smokers, the percentage of female smokers for the Standard, Light and Ultra Light brands was 51, 75 and $84 \%$ respectively. Smokers' ages ranged from 18 to over 55 years.

\section{Analytical procedures}

In Bristol the tipping papers were removed from each filter and sent to Novamann International Analytical Laboratories, Mississauga, Ontario, Canada. The remains of the tobacco rod was carefully removed from each remaining filter and the filters were sent to British American Tobacco's R\&D Centre in Southampton.

In Canada the tipping papers were sprayed with a $4 \%$ aqueous solution of ninhydrin and placed in an oven at $200{ }^{\circ} \mathrm{C}$ for two minutes. The ninhydrin reacted with amino acids in the dried saliva on the tipping paper and the lip imprint developed as a pink or purple coloration. Maximum mouth insertion depths on each tipping paper were measured from the lip imprint.

In Southampton the nicotine was extracted from the filters by shaking in propan-2-ol for 20 minutes, usually in batches of 10 filters from each smoker, but sometimes in batches of 5 filters or singly. The nicotine was determined by packed column gas chromatography using $n$-heptadecane as internal standard. Preliminary experiments had shown that 20 minutes shaking was sufficient to remove all the nicotine from the filter tips since no extra nicotine was extracted even after a further 30 minutes heating under reflux. This was the case for single and multiple filter extractions. Other preliminary work had also shown that the nicotine content on the filter tips remained constant during seven weeks storage of the filters. In addition, the cigarettes were machinesmoked in Southampton under a variety of smoking parameters and with the filter ventilation zones deliberately blocked to various degrees with tape. The yields of 'tar' (nicotine-free dry particulate matter), nicotine and carbon monoxide were determined. Also, the filtration efficiencies of nicotine on the filters were determined under the various machine smoking conditions. Finally, the effect of partial blocking the ventilation zone on filter ventilation was also measured.

\section{DEVELOPMENT AND CONSIDERATION OF MOUTH INSERTION DEPTH TECHNIQUES}

Several independently conducted unpublished studies have measured the depth to which smokers insert cigarettes into their mouths and the techniques used have evolved since the 1970s. These studies have been recently reviewed (2). Most of the measurements have been made by examining used filter cigarette butts collected from ash trays in pubs, restaurants, shopping malls and other public areas and obtaining a visible imprint of the lip marks on the tipping paper. Other, laboratory-based studies have used videorecording of smokers, in profile, to measure the mouth insertion depths from the television screen when replaying the tapes.

\section{Table 1.}

Details of cigarettes.

\begin{tabular}{l|c|c|c|c|c}
\hline \multicolumn{1}{c|}{ Cigarette } & $\begin{array}{c}\text { Ventilation } \\
(\%)^{*}\end{array}$ & Width $(\mathrm{mm})$ & $\begin{array}{c}\text { Distance from mouth } \\
\text { end }(\mathrm{mm})\end{array}$ & 'Tar' & Nicotine \\
\hline & & & & & \multicolumn{2}{c}{ Standard yields $(\mathrm{mg})^{* *}$} \\
& & - & $12-16$ & 12 & 1.1 \\
Standard & 0 & 4 & $13.5-14.5$ & 4.3 & 0.89 \\
Light & 29 & 1 & & & 0.35 \\
Ultra Light & 56 & & & \\
\hline
\end{tabular}

* Measured at an air flow of $17.5 \mathrm{~mL} \mathrm{~s}^{-1}$

** $35 \mathrm{~mL}, 2$ s puff once per minute smoked to butt length of (filter overtipping +3 ) $\mathrm{mm}$. 
The earliest study in Germany in 1974 (3) used lipstick prints on the tipping as the basis of the measurement. Studies conducted in Germany, Switzerland and Canada in the 1980s were dependent on the detection of the enzyme $a$-amylase in dried saliva on the butts $(4,5)$. The method takes advantage of the fact that $a$-amylase catalyses the breakdown of starch to maltose. The reaction is extremely precise and the $a$-amylase in dried saliva is detectable even after several weeks (4). The $a$ amylase was transferred from the filter tipping paper onto a wet, starch impregnated strip of silica gel on aluminum foil. This was incubated at $37^{\circ} \mathrm{C}$ for 15 minutes and sprayed with iodine solution. The lip imprint became visible as white (degraded starch) on a blue-colored background (starch-iodine reaction). A variant of this technique was used by HILL in 1983 (6) in a laboratory-based study in which starch was applied to the filter prior to smoking. After smoking, the tipping paper was removed, sprayed with iodine solution, and the position of the smoker's lips was identified within the starch stain. Various preliminary experiments using the $a$-amylase method showed good correlations between the maximum insertion depths measured and direct video-recording observation of mouth insertion depth $(6,7)$.

Although very precise for the detection of saliva, the $a$ amylase technique involves a number of steps and is time consuming. More recent studies conducted in the USA and Canada $(8,9)$ have been based on the detection of amino acids in the dried saliva on the tipping using the more-rapid ninhydrin technique. This is the technique used in the present study. This is not a perfect technique and there are uncertainties in its use. For example, amino acids are present in all body fluids,

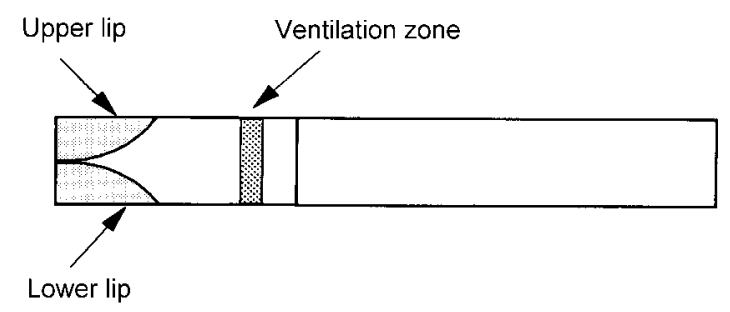

Imprint on tipping paper - one puff

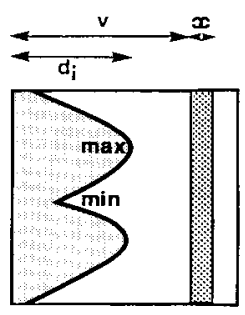

Multiple puffs

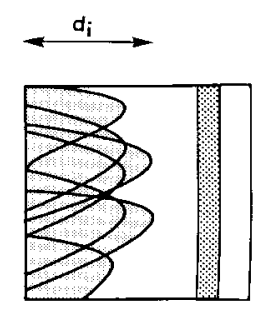

Figure 1.

Lip imprint measurements. including perspiration on fingers. Therefore, on occasions there are also finger marks observed on the ninhydrin-stained tipping papers in addition to the lip imprint. However, it is generally easy to distinguish the stained lip imprint from the stained finger marks.

Furthermore, results from the present study show that following the staining treatment, about $11 \%$ of the filter tipping papers examined had no distinct lip imprint or an abnormally shallow one (1 $\mathrm{mm}$ apparent insertion depth). This is presumably due to the smokers of these cigarettes having dry lips which did not leave any saliva on the filter. These cigarettes were smoked in the UK in May and June 1997, a relatively humid period. A similar study (9) in which filter butts were collected from indoor shopping malls in three Canadian cities during the winter of 1996/97, using the same ninhydrin technique undertaken at the same analytical laboratory, indicated that $19 \%$ of the filter tipping papers had no distinct lip imprint. The humidity in these environments in the winter would be much lower than in the UK in May/June resulting in an apparently higher proportion of smokers with dry lips.

From consideration of the topography of the lip imprint we can obtain an indication of the uncertainties inherent in measuring mouth insertion depths. As shown schematically in Figure 1, in a given puff there is a maximum insertion depth which occurs at the top and bottom of the filter due to contact with the upper and lower lips. There is also a minimum insertion depth which in a given puff is the point of lip contact at the side of the filter. When the tipping paper is removed from the filter after one puff, the lip imprint boundary line shows up approximately in the form of a sinusoidal curve (Figure 1). The culmination of several sinusoidal curves from each puff can become more or less a jagged line. As depicted in Figure 1, the measured insertion depth for a smoker with moist lips is the maximum insertion depth obtained during any single puff during the smoking of the cigarette.

\section{RESULTS AND DISCUSSION}

\section{Mouth insert depths}

The mean mouth insertion depths determined in this study are shown in Table 2, based on both the individual filter butt insertion depths and the mean insertion depths per smoker. The means based on individual butts are slightly higher than those based on individual smokers and the standard deviations are wider. For most of the smokers in this study, their individual insertion depths vary by less than $3 \mathrm{~mm}$. However, for a small proportion of smokers the 


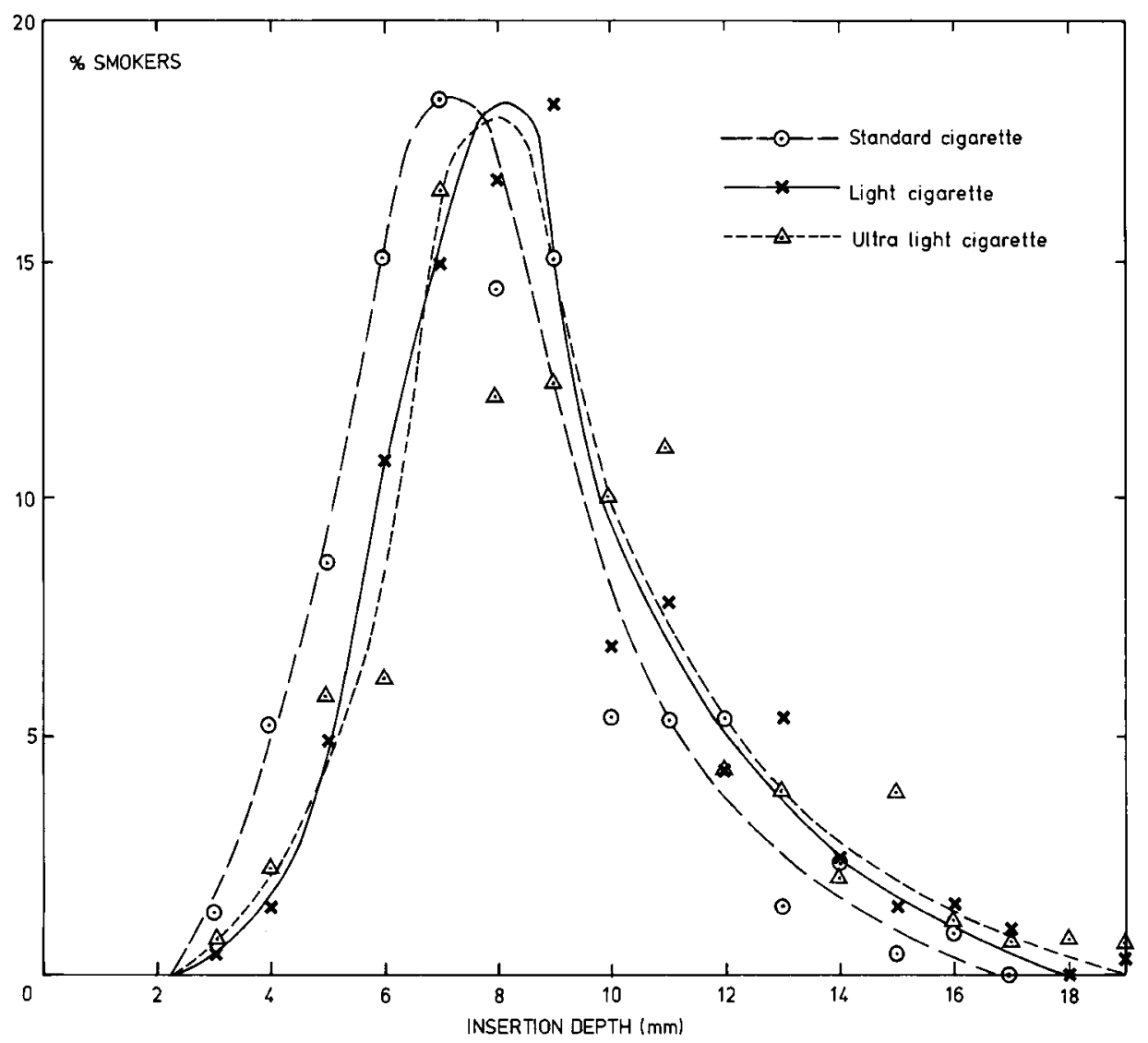

Figure 2.

Mouth insertion depth distributions.

individual insertion depths vary by more than $6 \mathrm{~mm}$. The mean insertion depths are significantly different:

Standard v. Lights, at $\mathrm{p}<0.001$

Standard v. Ultra Lights, at $\mathrm{p}<0.001$

Lights v. Ultra Lights, at $\mathrm{p}<0.05$.

The insertion depths have also been analyzed by gender. For a given brand there is no significant difference in mean insertion depths between male and female smokers.

The mean insertion depths $(7.6-9.4 \mathrm{~mm}$, based on individual smokers) are lower than most of those determined in other studies using similar tipping paper staining techniques (and consequently subject to similar uncertainties as those discussed above). Mean mouth insertion depths varying from 10.1 to $11.5 \mathrm{~mm}$ have been observed from studies conducted in Germany, Switzerland, Canada and the USA between 1974 and 1997 (3, 4, 5, 8, 9 and summarized in 2). The present mean results are, however, similar to those observed by HILL in 1983 and also with
British smokers (6 and also summarized in 2). HILL conducted two laboratory-based studies to measure insertion depths, the first study being based on videorecording of 23 smokers. HILL's second 1983 study used a variant of the a-amylase technique in which lines of starch were applied longitudinally, with a pen, to the filter prior to smoking. After smoking, the tipping paper was removed, sprayed with iodine solution, and the position of the smoker's lips was identified within the starch stain. HILL obtained mean, maximum insertion depths of 9.1 and $8.3 \mathrm{~mm}$ from the video and starch studies respectively, both similar to the means in the present study. Consequently, it would appear from both the present results and those of HILL in 1983, using different techniques, that British smokers are shorter mouth inserters on average than smokers in Germany, Switzerland, Canada and the USA.

The insertion depth distributions based on more than 200 smokers of each cigarette type are shown in Figure 2. The distributions and standard deviations about the mean are similar to those observed in other 
studies (2,9), ranging from about 3 to $24 \mathrm{~mm}$ and being slightly skewed towards higher insertion depths.

\section{Ventilation zone coverage by lips}

From a knowledge of the insertion depth on each tipping paper, and the known position of the ventilation zone (Table 1), the number of butts with part or all of the ventilation zone covered by the lips can be readily calculated.

\begin{tabular}{lcc}
\hline Cigarette & Light & $\begin{array}{c}\text { Ultra } \\
\text { Light }\end{array}$ \\
\hline Number of smokers: & 202 & 207 \\
Number of filters: & 1821 & 1852 \\
No vent coverage: & $1585(87 \%)$ & 1553 \\
& & $(84 \%)$ \\
Partial coverage: & 209 & 178 \\
& $(11.5 \%)$ & $(9.6 \%)$ \\
Complete coverage: & $27(1.5 \%)$ & 121 \\
& & $(6.5 \%)$ \\
\hline
\end{tabular}

Overall, for the two filter ventilated cigarettes, $15 \%$ of the stained butts examined had at least part of the vent zone covered by lips; $85 \%$ of the butts had no vent zone coverage. The distribution of the covered vent zone between partial and complete coverage has been calculated from the position of the vent zone as described in Reference 2. Given the uncertainties in the measured insertion depths, discussed above, these figures should be regarded as estimates of the incidence of vent blocking rather than absolute values. In particular, the distribution between partial and complete vent zone coverage by lips is likely to be approximate. Nevertheless, these figures are substantially less than the estimates of $50 \%$ vent zone coverage which have been quoted in the published literature (1).

\section{Estimated nicotine yields of the smokers}

The nicotine measured on the filters $(\Delta S \mathrm{mg})$ was converted to an estimated yield of the smoker $\left(S_{2} \mathrm{mg}\right)$ using the known filtration efficiencies $(\theta, \%)$ of the filter for nicotine:

$$
\begin{aligned}
\theta & =\frac{S_{1}-S_{2}}{S_{1}} \cdot 100 \\
& =\frac{\Delta S}{S_{2}+\Delta S} \cdot 100
\end{aligned}
$$

Table 2a.

Mean insertion depths: based on individual filter butts.

\begin{tabular}{l|c|c|c}
\hline Cigarette & Mean $(\mathrm{mm})$ & Standard Deviation & $\mathrm{n}$ \\
\hline Standard & & & 1802 \\
Light & 7.8 & 3.6 & 1821 \\
Ultra Light & 8.7 & 3.7 & 1852 \\
& 9.5 & 5.0 & \\
\hline
\end{tabular}

Table 2b.

Mean insertion depths: based on individual smokers.

\begin{tabular}{l|c|c|c}
\hline Cigarette & Mean $(\mathrm{mm})$ & Standard Deviation & $\mathrm{n}$ \\
\hline Standard & 7.6 & 2.7 & 207 \\
Light & 8.6 & 2.9 & 202 \\
Ultra Light & 9.4 & 4.2 & 207 \\
\hline
\end{tabular}


Table 3.

Effect of smoking regime on nicotine Filtration Efficiency (F.E.).

\begin{tabular}{c|c|c|c|c|c}
\hline \multicolumn{3}{c}{ Smoking Regime } & \multicolumn{3}{c}{ Nicotine F.E. (\%) } \\
\hline $\begin{array}{c}\text { Puff Volume } \\
(\mathrm{mL})\end{array}$ & $\begin{array}{c}\text { Duration } \\
(\mathrm{s})\end{array}$ & $\begin{array}{c}\text { Frequency } \\
(\mathrm{s})\end{array}$ & $\begin{array}{c}\text { Standard } \\
\text { Cigarette }\end{array}$ & $\begin{array}{c}\text { Light } \\
\text { Cigarette }\end{array}$ & $\begin{array}{c}\text { Ultra Light } \\
\text { Cigarette }\end{array}$ \\
\hline & 2 & & & & \\
35 & 2 & 60 & 39.8 & 41.8 & 53.3 \\
45 & 2 & 60 & 41.1 & 40.0 & 49.9 \\
55 & 2 & 60 & 36.6 & 37.0 & 47.2 \\
70 & 1.5 & 60 & 36.3 & 35.6 & 45.9 \\
45 & 2 & 60 & 34.8 & 34.7 & 47.0 \\
45 & & 35 & 39.5 & 38.3 & 48.4 \\
\hline
\end{tabular}

Table 4.

Effect of partial blocking of ventilation zone on nicotine Filtration Efficiency (F.E.)

\begin{tabular}{|c|c|c|c|}
\hline$\%$ Ventilation Zone & \multicolumn{3}{|c|}{ Nicotine F.E. $(\%)^{*}$} \\
\hline Blocked & Standard Cigarette & Light Cigarette & Ultra Light Cigarette \\
\hline 0 & 40.2 & 41.8 & 51.4 \\
\hline 25 & & 43.4 & 52.2 \\
\hline 50 & & 42.7 & 50.8 \\
\hline 75 & & 41.2 & 48.7 \\
\hline 100 & & 41.6 & 49.0 \\
\hline
\end{tabular}

* $35 \mathrm{~mL}, 2 \mathrm{~s}$ puff once per minute smoked to butt length of (filter overtipping +3 ) $\mathrm{mm}$.

where:

$S_{1}$ is the weight of nicotine input to the filter during smoking,

$S_{2}$ is the weight of nicotine exiting the filter during smoking,

and $\Delta S$ is the amount of nicotine retained on the filter during smoking, $=\mathrm{S}_{1}-\mathrm{S}_{2}$.

Nicotine filtration efficiencies have been determined for the three filters used in the present study at a variety of different smoking regimes and also at different levels of filter ventilation zone blockage at one of the smoking regimes. These different conditions are likely to cover the full range of smoking regimes which human smokers may be expected to take $(2,10)$. The results are shown in Tables 3 and 4 .

The results in Table 3 indicate that the nicotine filtration efficiencies fall as the puffing velocity (puff volume/duration) increases with some evidence of a minimum filtration efficiency at a puffing velocity of about $32 \mathrm{~mL} \mathrm{~s}^{-1}$. This has been observed in other studies $(11,12,13)$. The results in Table 4 indicate that at a $35 / 2 / 60$ smoking regime the effect of blocking the vent zone on nicotine filtration efficiency is small. This is in 
Table 5.

Estimated mean nicotine yields of the smokers.

\begin{tabular}{l|c|c|c}
\hline Cigarette & Standard & Light & Ultra Light \\
\hline Machine yield* $(\mathrm{mg})$ & 1.1 & 0.89 & 0.35 \\
\hline & & & 0.45 \\
Mean yield of the smokers (mg) & 0.87 & 0.71 & 0.14 \\
Standard deviation & 0.27 & 0.28 & 0.31 \\
Standard deviation/mean yield of the smokers & 0.31 & 197 & 195 \\
\hline
\end{tabular}

* One $35 \mathrm{~mL}, 2$ s puff once per minute to butt length of (overtipping +3 ) mm

agreement with previous studies $(11,14)$ which have shown that the effect of level of filter ventilation has only a small effect on particulate phase filtration efficiency of the filter. Since all the effects on a given filter depicted in Tables 3 and 4 are relatively low, overall mean values of nicotine filtration efficiencies of 38,40 and $49 \%$ have subsequently been used for the filters on the Standard, Light and Ultra Light cigarettes respectively.

Based on these mean nicotine filtration efficiencies,

Table 6.

Effect of partial blocking of ventilation zone on filter ventilation, $F_{\mathrm{v}}$, and mainstream yields*.

\begin{tabular}{|c|c|c|c|c|c|c|}
\hline \multirow{2}{*}{ Cigarette } & \multirow{2}{*}{$\begin{array}{c}\% \text { Vent Zone } \\
\text { Blocked }\end{array}$} & \multirow{2}{*}{$F_{v}(\%)^{\star *}$} & \multicolumn{3}{|c|}{ Yield (mg/cig) } & \multirow{2}{*}{$\begin{array}{l}\text { Puff } \\
\text { No. }\end{array}$} \\
\hline & & & 'Tar' & Nicotine & $\mathrm{CO}$ & \\
\hline \multirow[t]{5}{*}{ Light } & 0 & 28.7 & 9.3 & 0.89 & 8.7 & 9.1 \\
\hline & 25 & 23.7 & 9.4 & 0.90 & 9.7 & 9.0 \\
\hline & 50 & 18.6 & 10.1 & 0.97 & 10.1 & 8.9 \\
\hline & 75 & 9.9 & 10.6 & 0.96 & 11.4 & 8.3 \\
\hline & 100 & 0.0 & 10.8 & 0.99 & 12.7 & 8.3 \\
\hline \multirow[t]{5}{*}{ Ultra Light } & 0 & 56.4 & 4.1 & 0.35 & 4.0 & 7.9 \\
\hline & 25 & 47.7 & 4.4 & 0.39 & 5.1 & 7.9 \\
\hline & 50 & 37.5 & 5.2 & 0.44 & 6.3 & 7.4 \\
\hline & 75 & 23.9 & 6.6 & 0.50 & 8.7 & 7.2 \\
\hline & 100 & 0.0 & 7.5 & 0.53 & 11.0 & 6.9 \\
\hline
\end{tabular}

* $35 \mathrm{~mL}, 2 \mathrm{~s}$ puff once per minute smoked to butt length of (filter overtipping +3 ) $\mathrm{mm}$.

${ }^{* *}$ Measured at an air flow of $17.5 \mathrm{~mL} \mathrm{~s}^{-1}$. 
estimates of nicotine yields of the smokers have been made using equation [1] and the nicotine levels measured on the filter butts. The estimates are depicted in Table 5 and Figure 3. The distribution curves for the estimated smoke nicotine yields of the smokers in Figure 3 are separated, especially for the Ultra Light cigarette. There is some overlap, especially between the Standard and Light cigarette. However, it should be noted that the machinesmoked nicotine yields at the 35/2/60 smoking regime from the Standard and Light cigarettes are also fairly close (1.1 and $0.89 \mathrm{mg}$ respectively). The distribution curves (Figure 3), and mean nicotine yields of the smokers (Table 5) are in the order of the cigarette delivery category: Standard (full flavor) > Light $>$ Ultra Light.

Thus the estimated nicotine yield distributions of the smokers are dependent on cigarette type although there is some overlap. The three distributions have similar shapes, being slightly skewed towards the higher yields (Figure 3). The standard deviations relative to the mean yield for each cigarette type are very similar whichever set of filtration efficiencies is used (Table 5). Thus, based on these results, it appears that the range of nicotine yields which humans can obtain from a given cigarette, relative to the mean nicotine, is independent of cigarette type: ventilated or non-ventilated.

\section{Comparison of nicotine yields and mouth insertion depths}

Estimated nicotine yields of the smokers and mean mouth insertion depths per smoker can be compared to see what effect vent zone coverage, as it occurs in practice, has on yields. The comparisons are shown in Figure 4 for the two filter ventilated cigarettes. At a given insertion depth there is a large variation in yield, due to differences in smoking behavior parameters such as puff volume, frequency and number. The position of the start of the vent zone is also shown in Figure 4. This separates smokers whose

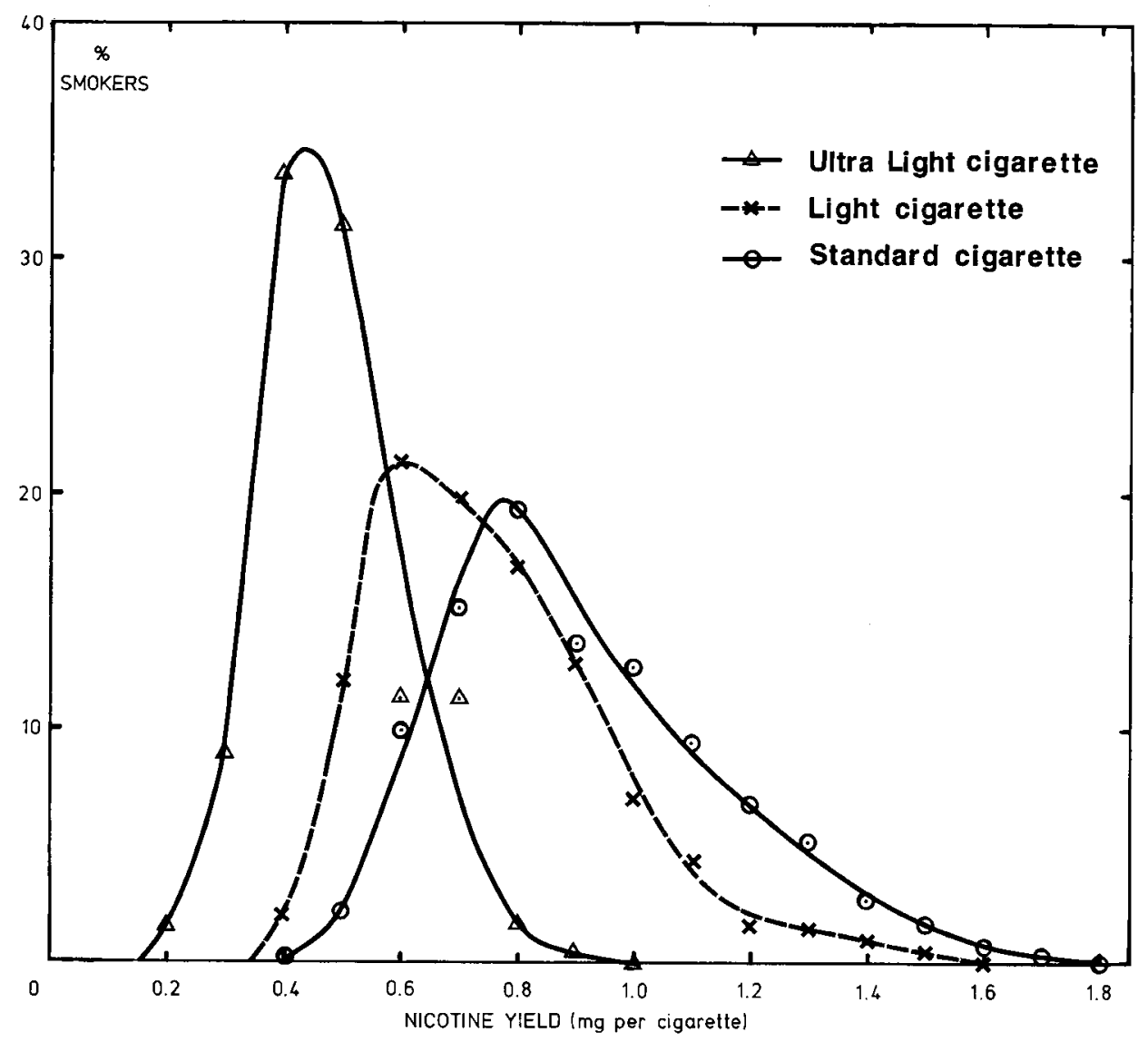

Figure 3.

Estimated nicotine yield distributions of smokers. 
(a) Light cigarette

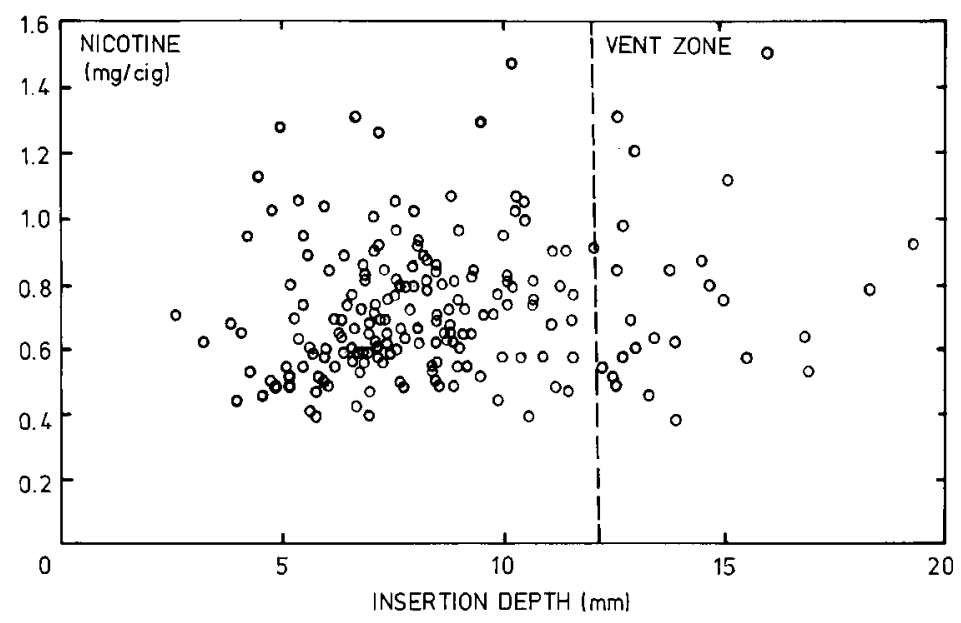

(b) Ultra Light cigarette

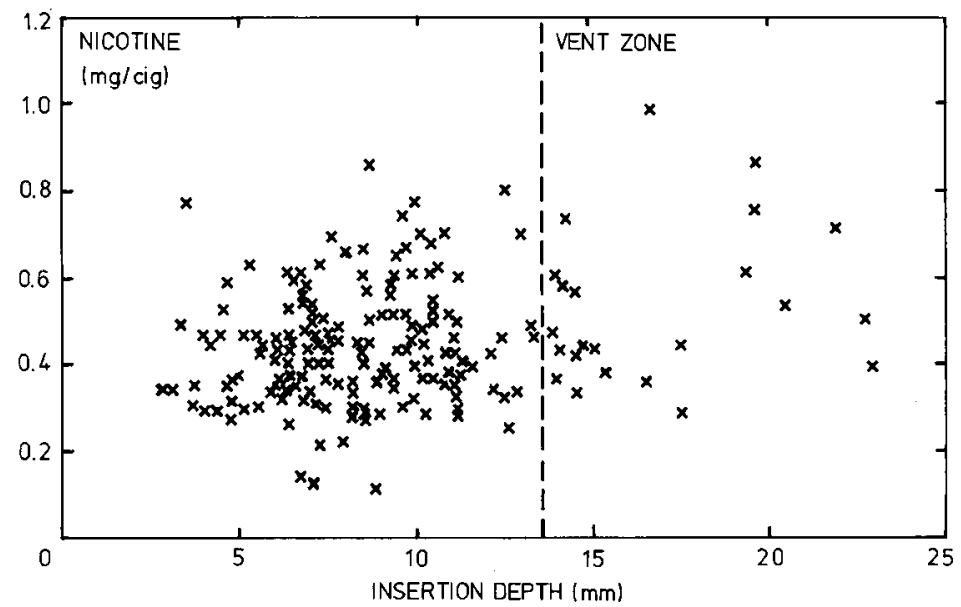

Figure 4.

Estimated nicotine yields and insertion depths.

insertion depths are too short to cover any of the vent zone from those where at least part of the zone is covered by lips. There is no noticeable difference in nicotine yields or scatter on either side of the vent zone position for either of the filter ventilated cigarettes.

As discussed above, there is some uncertainty in the insertion depths measured by the ninhydrin technique. However, even with this uncertainty, the results of the present study, taken as a whole, indicate that coverage of the filter vent zone by lips as it occurs in practice has a relatively minor effect on nicotine yields compared to other smoker behavior factors. This conclusion is substantiated further by considerations given in the next section.

\section{Effect of partial blocking on filter ventilation and mainstream yields}

The effects of partial blocking of the filter ventilation zone on filter ventilation, puff number and the mainstream yields of 'tar', nicotine and carbon monoxide, are shown in Table 6 and Figure 5. The relationship between degree of vent blocking and filter ventilation is non- 


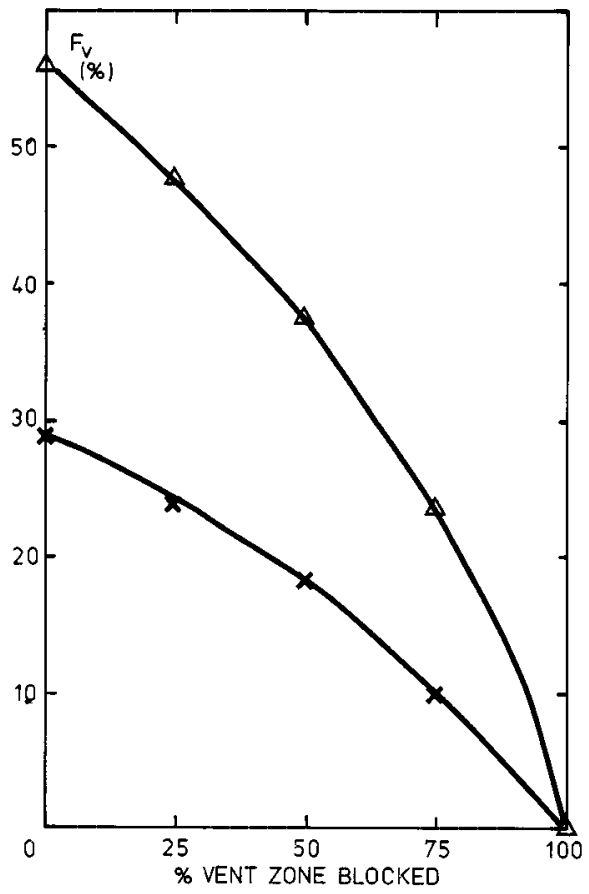

\section{$\times$ Light cigarette \\ $\triangle$ Ultra Light cigarette}
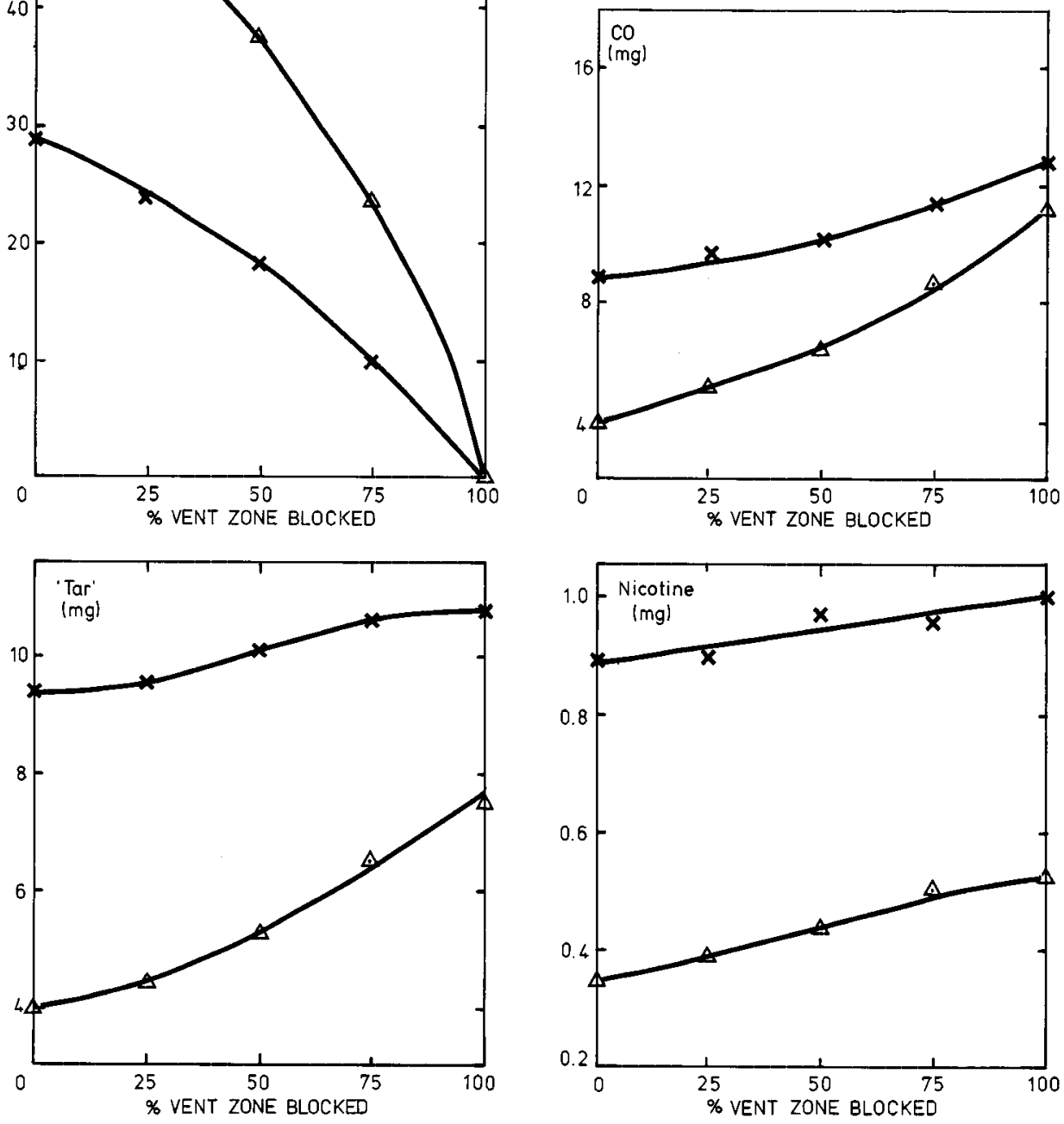

Figure 5.

Effect of vent blocking on filter ventilation and mainstream yields.

linear, as has been observed in previous studies (2). The non-linearity increases as the level of filter ventilation increases, again as has been observed previously (2). Previous studies have also shown that the effect of filter vent blocking on mainstream smoke yields is also nonlinear $(2,15,16)$. This is confirmed in the present study for 'tar' and carbon monoxide yields, especially with the Ultra Light cigarette. The effect of vent blocking on nicotine smoke yields for the two cigarettes examined in the present study is virtually linear.

The effect of partial and complete blocking of the filter vent zone on the smoking machine yields with both filter ventilated cigarettes are in the order of $\mathrm{CO}>$ 'tar' > nicotine. This order has also been reported by REEVES and co-workers (17) with partial and complete blocking of three types of filter ventilated cigarette. It is also consistent with the findings of a review of several studies on the relative reductions of these smoke components by the introduction of filter ventilation (18).

The mouth insertion results, presented above, indicate that about $15 \%$ of the 3673 filter ventilated butts examined showed evidence of some vent zone coverage by the lips during at least one puff. The bulk of this coverage was partial. RÖPER has undertaken image analysis of those lip imprints that cover filter ventila- 
tion holes in a single puff $(15$, discussed in 2$)$. His results indicate that the maximum coverage that is likely to occur in practice for the majority (over 80 $\%)$ of those smokers who do cover the vents in a given puff is $50 \%$ of the zone covered. This amount of vent blocking in every puff would increase the standard machine (35/2/60) 'tar' yield of the Light cigarette from 9.3 to $10.1 \mathrm{mg}$, and the 'tar' yield of the Ultra Light cigarette from 4.1 to $5.2 \mathrm{mg}$ (see Table 6 and Figure 5 for equivalent effects on nicotine and carbon monoxide yields).

These increases in 'tar' yields are clearly very small. It is not possible to state that such relatively small increases would occur with those $15 \%$ of human smokers who do cover the vent zone with their lips because, of course, humans do not smoke in the same way as the standard 35/2/60 machine smoking regime. However, it can be implied from consideration of three human smoking characteristics that the effect of inadvertent vent blocking by humans could be even smaller than those in Table 6. These considerations are:

i. The decreases in puff volumes with each successive puff that are known to occur as humans smoke the cigarette (19-23).

ii. The decreases in puff volume and puff number that have been observed independently by ZACNY et al. (24) and REEVES et al. (17) with actual smokers when ultra low 'tar' cigarettes had 0,50 and $100 \%$ of their filter ventilation zone deliberately and systematically blocked with tape by the experimenter.

iii. It is unlikely that the smoker would cover the filter vent zones with his/her lips in every puff.

\section{CONCLUSIONS}

1. Based on the ninhydrin staining technique, British smokers have an overall mean mouth insertion depth of about $8.5 \mathrm{~mm}$. This is smaller than the means observed in other studies conducted in Germany, Switzerland, USA and Canada using similar techniques (10.1 - 11.5 $\mathrm{mm})$. It is, however, consistent with the results of other studies conducted in Britain in 1983.

2. $85 \%$ of the 3673 stained ventilated filters examined from 409 smokers showed no evidence of vent zone coverage by lips. $15 \%$ of the filters showed evidence that at least part of the vent zone had been covered by lips.

3. Estimated nicotine yield distributions of the smokers from the three cigarettes used in this study are dependent on cigarette type although there is some overlap. The distributions are in the order of delivery category: Standard (full flavor) $>$ Light $>$ Ultra Light. The range of nicotine yields which humans can obtain from a given cigarette, relative to the mean nicotine, is almost the same for the three cigarettes used in this study.

4. The presence or absence of filter ventilation zone coverage as indicated by the ninhydrin filter staining pattern is not reflected in the estimated nicotine yields to smokers. It is likely that other smoker behavior factors have a more substantial role in determining nicotine yields within each cigarette delivery category.

5. For those $15 \%$ of smokers who do cover the vent holes, the coverage is partial for most of them, with a maximum of about half of the vent zone covered. Furthermore, non-linear relationships exist between proportion of holes blocked, total ventilation and mainstream yields. Thus the maximum partial coverage of the vent zone in all puffs would increase the standard $(35 / 2 / 60)$ machine yield of 'tar' of the Light cigarette from 9.3 to $10.1 \mathrm{mg}$, and from 4.1 to $5.2 \mathrm{mg}$ for the Ultra Light cigarette. These increases in machine smoking yields are small. Consideration of other human smoking factors implies that the relative increase with buman smoking could be even smaller.

6. The effect of partial and complete blocking of the filter vent zone on the smoking machine yields are in the order of $\mathrm{CO}>$ 'tar' > nicotine.

\section{REFERENCES}

1. Kozlowski, L.T. and C.T. Sweeney: Low-yield, light and ultra-light cigarettes: Let's understand the product before we promote; in: Social Marketing: Theoretical and Practical Perspectives, edited by M.E. Goldberg, M. Fishbein and S.E. Middlestadt, Lawrence Erlbaum Associates, Mahwah, New Jersey, USA, 1997, pp 231- 244.

2. Baker, R.R. and L.S. Lewis: Filter ventilation has there been a "cover-up"?; Recent Advances in Tobacco Science 23 (1997) 152-196.

3. Schulz, W., British American Tobacco, Germany, unpublished results, 1974.

4. Barkemeyer, H., W. Schulz and F. Seehofer, British American Tobacco, Germany, unpublished results, 1984.

5. McBride, C., Imperial Tobacco, Canada, unpublished results, 1984.

6. Hill, C.A., Imperial Tobacco, UK, unpublished results, 1983.

7. Wiethaup, W., British American Tobacco, Germany, unpublished results, 1984. 
8. Lewis, L.S., R.J. Reynolds Tobacco Company, USA, unpublished results, 1995.

9. Porter, A.R. and P.J. Dunn: Mouth insertion depths in Canadian smokers; Proceedings of the CORESTA Smoke and Technology Groups' Joint Meeting, Hamburg, Germany, September 1997, 35-43.

10. Thornton, R.E.: Smoking behaviour, physiological and psychological influences; Churchill Livingstone, London, 1978.

11. Eaker, D.W.: Dynamic behavior and filtration of mainstream smoke in the tobacco column and filter; Recent Advances in Tobacco Science 16 (1990) 103-187.

12. Overton, J.R.: Filtration of cigarette smoke: relative contributions of inertial impaction, diffusional deposition and direct interception; Beitr. Tabakforsch. 7 (1973) 117-120.

13. Dwyer, R.W. and S.G. Abel: The efficiencies of cellulose acetate filters; Beitr. Tabakforsch. Int. 13 (1986) 243-253.

14. Mathis, D.E.: Filtration efficiency in ventilated cigarettes; Paper presented at 36th Tobacco Chemists' Research Conference, Raleigh, NC, USA, October 1982.

15. Röper, W., Reemtsma, Germany, unpublished results, 1997.

16. Darrall, K.G.: Smoking machine parameters and cigarette smoke yields; The Science of the Total Environment 74 (1988) 263-278.

17. Reeves, N., M. Dixon, N. Ayya, D. Hilton and F.K. St. Charles: Measurement of puffing behaviour in lights and ultra lights smokers with ventilation holes partially and fully blocked; Proceedings of the CORESTA Smoke and Technology Groups' Joint Meeting, Hamburg, Germany, September 1997, 62-70.

18. Baker, R.R.: The effect of ventilation on cigarette combustion mechanisms; Recent Advances in Tobacco Science 10 (1984) 88-150.
19. Nemeth-Coslett, R. and R.R. Griffiths: Effects of cigarette rod length on puff volume and carbon monoxide delivery in cigarette smokers; Drug Alcohol Depend. 15 (1985) 1-13.

20. Guyatt, A.R., A.J.T. Kirkham, A.G. Baldry, M. Dixon and G. Cumming: How does puffing behaviour alter during the smoking of a single cigarette?; Pharmacol. Biochem. and Behav. 33 (1989) 189-195.

21. Kolonen, S., J. Tuomisto, P. Puustinen and M.M. Airaksinen: Puffing behaviour during the smoking of a single cigarette in a naturalistic environment; Pharmacol. Biochem. and Behav. 41 (1992) 701-706.

22. Reeves, N. and M. Dixon: The measurement of human smoking behaviour and the influence of mainstream smoke deliveries on changes in behavioural parameters; (i). Proceedings of the CORESTA Smoke and Technology Groups' Joint Meeting, Vienna, Austria, September 1995, 141-148; (ii) Beitr. Tabakforsch. Int. 16 (1995) 134.

23. Bentrovato, B., A. Porter, M. Youssef and P.J. Dunn: Variations in tar, nicotine and carbon monoxide deliveries obtained by smokers of the same brand; (i) Proceedings of the CORESTA Smoke and Technology Groups' Joint Meeting, Vienna, Austria, September 1995, 151-165; (ii) Beitr. Tabakforsch. Int. 16 (1995) 132-134.

24. Zacny, J.P., M.L. Stitzer and J.E. Yingling: Cigarette filter vent blocking: Effects on smoking topography and carbon monoxide exposure; Pharmacol. Biochem. and Behav. 25 (1986) 1245-1252.

Address for correspondence:

Richard R. Baker,

British American Tobacco,

Research and Development Centre,

Regent's Park Road,

Southampton SO15 8TL

U.K. 